Article

\title{
Visible-Light-Driven Photocatalytic Inactivation of Bacteria, Bacteriophages, and Their Mixtures Using ZnO-Coated HDPE Beads as Floating Photocatalyst
}

\author{
Marius Urbonavicius ${ }^{1, *(\mathbb{D})}$, Sarunas Varnagiris ${ }^{1}$, Simona Tuckute ${ }^{1}$, Sandra Sakalauskaite ${ }^{2}$, Emilija Demikyte ${ }^{2}$ (D) \\ and Martynas Lelis ${ }^{1}$
}

\section{Citation: Urbonavicius, M.;}

Varnagiris, S.; Tuckute, S.;

Sakalauskaite, S.; Demikyte, E.; Lelis,

M. Visible-Light-Driven

Photocatalytic Inactivation of

Bacteria, Bacteriophages, and Their

Mixtures Using ZnO-Coated HDPE

Beads as Floating Photocatalyst.

Materials 2022, 15, 1318. https://

doi.org/10.3390/ma15041318

Academic Editor:

Massimo Calamante

Received: 14 January 2022

Accepted: 7 February 2022

Published: 10 February 2022

Publisher's Note: MDPI stays neutral with regard to jurisdictional claims in published maps and institutional affiliations.

Copyright: (c) 2022 by the authors. Licensee MDPI, Basel, Switzerland. This article is an open access article distributed under the terms and conditions of the Creative Commons Attribution (CC BY) license (https:// creativecommons.org/licenses/by/ $4.0 /)$.
1 Center for Hydrogen Energy Technologies, Lithuanian Energy Institute, 3 Breslaujos, 44403 Kaunas, Lithuania; sarunas.varnagiris@lei.lt (S.V.); simona.tuckute@lei.lt (S.T.); martynas.lelis@lei.lt (M.L.)

2 Department of Biochemistry, Faculty of Natural Sciences, Vytautas Magnus University, 44404 Kaunas, Lithuania; sandra.sakalauskaite@vdu.lt (S.S.); emilija.demikyte@vdu.lt (E.D.)

* Correspondence: marius.urbonavicius@lei.lt; Tel.: +370-37-401-824
Abstract: Semiconductor materials used as photocatalysts are considered among the most effective ways to treat biologically polluted water. Certainly, efficiency depends on the selection of photocatalyst and its substrate, as well as the possibility of its application in a broader spectrum of light. In this study, a reactive magnetron sputtering technique was applied for the immobilisation of $\mathrm{ZnO}$ photocatalyst on the surface of HDPE beads, which were selected as the buoyant substrates for enhanced photocatalytic performance and easier recovery from the treated water. Moreover, the study compared the effect on the inactivation of the microorganism between ZnO-coated HDPE beads without $\mathrm{Ni}$ and with $\mathrm{Ni}$ underlayer. Crystal structure, surface morphology, and chemical bonds of as-deposited $\mathrm{ZnO}$ films were investigated by $\mathrm{X}$-ray diffraction, scanning electron microscopy, and $\mathrm{X}$-ray photoelectron spectroscopy, respectively. Visible-light-induced photocatalytic treatment was performed on the Gram-negative and Gram-positive bacteria and bacteriophages PRD1, T4, and their mixture. Higher bacteria inactivation efficiency was obtained using the ZnO photocatalyst with Ni underlayer for the treatment of S. Typhimurium and M. Luteus mixtures. As for infectivity of bacteriophages, T4 alone and in the mixture with PRD1 were more affected by the produced photocatalyst, compared with PRD1.

Keywords: floating photocatalyst; visible light; ZnO films; reactive magnetron sputtering; Ni underlayer; S. Typhimurium; M. Luteus; bacteriophages

\section{Introduction}

Water is the most crucial natural resource. It is known that about $2.5 \%$ of total water is classified as fresh water, while only $0.002 \%$ is recognised as humanly accessible $[1,2]$. Various researchers agreed that the capability to access freshwater resources is and will be an even greater issue shortly in the future. Among various issues regarding the scarcity of fresh water, water pollution plays one of the most important roles. The wide variety of pollutants (e.g., bacteria, dyes, pharmaceuticals, pesticides, bacteriophages, etc.) produced due to human activities can negatively influence ecosystems as well as human health. Nowadays, conventional wastewater treatment processes (WWTPs) are generally used for wastewater treatment. Unfortunately, various reports are showing that such treatment often contains biological contaminants and traces of emerging chemical pollutants. Even more, some researchers considered WWTPs as gateways of biological contaminants into the aquatic environment or as hot spots for antibiotic resistance proliferation [3-6]. Such a possibility for these constituents to enter the environment is considered a severe public health issue including various diseases such as diarrhoea, vomiting, abdominal discomfort, 
gastroenteritis, etc. [7]. Therefore, various researchers focused on the investigation of novel and effective treatment methods, which could detoxify various biological contaminants.

In this regard, advanced oxidation processes (AOPs), such as heterogeneous photocatalysis with semiconductor materials, are recognised as an effective way in organic wastewater treatment. Among various semiconductor materials applied for photocatalytic biological contaminants inactivation, $\mathrm{ZnO}$, which belongs to II-VI class of semiconductors, is depicted as one of the most promising materials. $\mathrm{ZnO}$ is known as a good photocatalyst for its optical and chemical properties, nontoxic nature, high exciton energy (60 meV) even at room temperature, and high oxidation capacity. Additionally, it is easy to grow or deposit a hexagonal $\mathrm{ZnO}$ wurtzite structure, which is a thermodynamically stable phase. Due to its environmentally friendly characteristic, $\mathrm{ZnO}$ is compatible with living organisms. Therefore, it has a broad range of daily applications by not leaving risks to human health and environmental impacts [8]. Meanwhile, during wastewater treatment or purification, $\mathrm{ZnO}$ can be adsorbed on the surface of biological contaminants and inhibit the growth of microorganisms [9]. However, the main drawbacks of $\mathrm{ZnO}$ are relatively high recombination of $\mathrm{e}^{-} / \mathrm{h}^{+}$as a single system, wide bandgap nature (about $\left.3.36 \mathrm{eV}\right)$, and severity to be activated under daylight irradiation [10-13]. Only $4 \%$ of the UV portion of solar energy can be utilised for $\mathrm{ZnO}$ photoexcitation in the photocatalytic process. Therefore, it is required to extend $\mathrm{ZnO}$ photoresponse into the visible-light region ( $43 \%$ of solar spectrum) [14]. Additionally, due to the fast recombination of UV or visible light photogenerated electron-hole pairs, photocatalytic efficiency is suppressed [15]. Therefore, in order to separate electrons and holes, new energy levels in the bandgap need to be created. Various techniques are investigated to overpass these issues, including doping of metal/nonmetal elements, coupling with other semiconductors, deposition of noble metals, etc. [16-21]. For instance, Y. Jiang et al. investigated the possibility to immobilise zeolitic imidazole-based metal-organic framework into $\mathrm{ZnO}$ structure. They showed effective E. coli bacteria inactivation results under visible-light irradiation, while disinfection in water can be fully completed in $50 \mathrm{~min}$ [22]. Another group with Z. Mirzaeifard et al. analysed S-doped $\mathrm{ZnO}$ nanoparticles under visible-light irradiation for $\mathrm{RhB}$ degradation. They showed that such a combination could decompose $100 \%$ of $\mathrm{RhB}$ in $90 \mathrm{~min}$. Moreover, the cycling experiment showed $92 \%$ decomposition after five consecutive reactions [23]. Meanwhile, some authors suggest that doping or other types of $\mathrm{Ni}$ and $\mathrm{ZnO}$ combination can be a suitable way to improve $\mathrm{ZnO}$ characteristics [24-27]. Moreover, our previous study revealed that $\mathrm{Ni}$ underlayer improves $\mathrm{TiO}_{2}$ photocatalytic efficiency, which was applied as floating photocatalyst for Salmonella typhimurium inactivation under visible-light irradiation [28].

Floating photocatalysts are an on-top option for wastewater treatment, where photocatalyst is immobilised on the floatable substrate. The main advantage of this technique against other photocatalyst methods is the possibility to employ the maximum light irradiation, which invokes intensive formation of reactive oxygen species (ROS) and enhances the photocatalytic performance $[29,30]$. Generally, floatable substrates have significantly larger sizes than powders. Therefore, the separation of such materials after wastewater treatment is a much easier process, compared with powdered photocatalysts. There are various articles showing improvement of photocatalytic performance using floating photocatalyst by decomposing various bacteria [31-35].

The analysis of one-type bacteria inactivation is a relatively simple and effective way to evaluate photocatalyst capability to decompose biological contaminants. Therefore, the majority of the research studies provide experiments regarding one type of contaminant (generally it is bacteria, such as Escherichia coli or Salmonella enterica). Still, the real condition wastewater might involve various types of diverse contaminants. Therefore, the investigation of biological contaminants mixture inactivation by photocatalytic materials is very important as well. Various articles have analysed diverse contaminants mixtures inactivation by photocatalysis. For instance, Pseudomonas aeruginosa and Bacillus subtilis [3], virus/bacteria system [36], organic micropollutants, human pathogen indicators, antibiotic- 
resistant bacteria and related genes [37], Shigella species and Vibrio cholera [38], Mycobacterium kansasii, and Mycobacterium avium [39], Escherichia coli and Pseudomonas aeruginosa [40], etc. mixtures were used for photocatalytic inactivation experiments. Unfortunately, there is a lack of scientific reports investigating the application of floating photocatalysts on the inactivation of biological contaminants mixtures. Moreover, the photocatalytic inactivation experiments of viruses or their mixtures are even more uncommon, because such experiments require a corresponding number of the specific host cells for their replication [41].

Therefore, in this study, we investigate photocatalytic inactivation of bacteria mixture and bacteriophages mixture initiated by a combination of visible-light and $\mathrm{ZnO}$-based floating photocatalyst. Specifically, the bacteria mixture consists of Gram-negative (Salmonella typhimurium) and Gram-positive (Micrococcus luteus) bacteria. Meanwhile, the bacteriophages mixture involves PRD1 and T4. The T4 is a relatively stable bacteriophage, which reactivates under UV irradiation, while PRD1 is a lipid envelope containing phage [42]. High-density polyethylene (HDPE) beads were selected as floatable substrates due to proper characteristics, which are listed elsewhere [43]. Part of HDPE beads was precovered by a thin nickel underlayer to test if it improves the photocatalytic activity in the case of $\mathrm{ZnO}$. Our previous studies [28,44] showed that the metallic underlayer can positively affect photocatalytic performance under both UV-B and visible light irradiation. Additionally, some studies suggest that the recombination rate of electron-hole can be reduced and photocatalytic efficiency improved using metallic substrates and transition metals dopants [45-47]. Another study reported that photocatalytic performance (including charge separation and absorption of visible light) can be enhanced by coupling semiconductors (such as $\mathrm{TiO}_{2}, \mathrm{ZnO}, \mathrm{Cu}_{2} \mathrm{O}, \mathrm{CdS}$, etc.) with metals [48]. In our case, the magnetron sputtering technique was applied for the $\mathrm{ZnO}$ photocatalyst immobilisation onto HDPE beads (with or without Ni underlayer), which, in our experience, is a suitable method for photocatalyst formation onto floatable substrates $[49,50]$. The obtained results revealed characteristics of both bacteria and bacteriophage mixtures inactivation using ZnO-based floating photocatalyst under visible-light irradiation.

\section{Methodology}

\subsection{ZnO Film Deposition on the Floating Substrate}

Deposition of $\mathrm{ZnO}$ films on the surface of HDPE beads (obtained from GoodFellow, Huntingdon, UK) with and without Ni underlayer was performed by reactive magnetron sputtering technique in a custom modified physical vapour deposition system (PVD-75, Kurt J. Lesker Company, Jefferson Hills, PA, USA) (Figure 1). Prior to the ZnO deposition, the HDPE beads were precovered with a thin layer of $\mathrm{Ni}$ (thickness of about $100 \mathrm{~nm}$ ) using magnetron with Ni target (purity 99.99\%, Kurt J. Lesker Company, Clairton, PA, USA) powered by a direct current power source. Our previous study disclosed that metallic underlayers can have positive impacts on the bactericidal effect of the photocatalyst under visible-light irradiation [28]. During the process, HDPE beads were placed under the unbalanced magnetron with a circular Zn target $(99.99 \%$ purity and $76 \mathrm{~mm}$ diameter, Kurt J. Lesker Company, Clairton, PA, USA) which was powered by an RF power source working at $150 \mathrm{~W}$ for $1 \mathrm{~h}$. After that, the HDPE beads were flipped over, and $\mathrm{ZnO}$ film was deposited on the other side of the beads under the same conditions. The distance between the HDPE beads and $\mathrm{Zn}$ target was $7 \mathrm{~cm}$. The $\mathrm{ZnO}$ film was deposited at a fixed pressure of $1 \times 10^{-2}$ mbar which was preselected experimentally as an optimal one according to our previous study [51]. Ar and $\mathrm{O}_{2}$ gas mass flow controllers (MFC) were connected to the Process Control and Plasma Emission Monitoring System (Flotron X, Nova Fabrica Ltd., Ignalina, Lithuania) which ensured a constant pressure and an accurate Ar and $\mathrm{O}_{2}$ gas flow ratio (4:1) according to the changes of $\mathrm{Zn}$ emission intensity. In order to measure the thickness of $\mathrm{ZnO}$ film, the film was deposited on the flat quartz substrate under similar reactive magnetron sputtering conditions. The approximate thickness of $\mathrm{ZnO}$ film measured by stylus profilometer (Ambios XP-200, Ambios Technology, Santa Cruz, CA, USA) was $4-5 \mu \mathrm{m}$. 


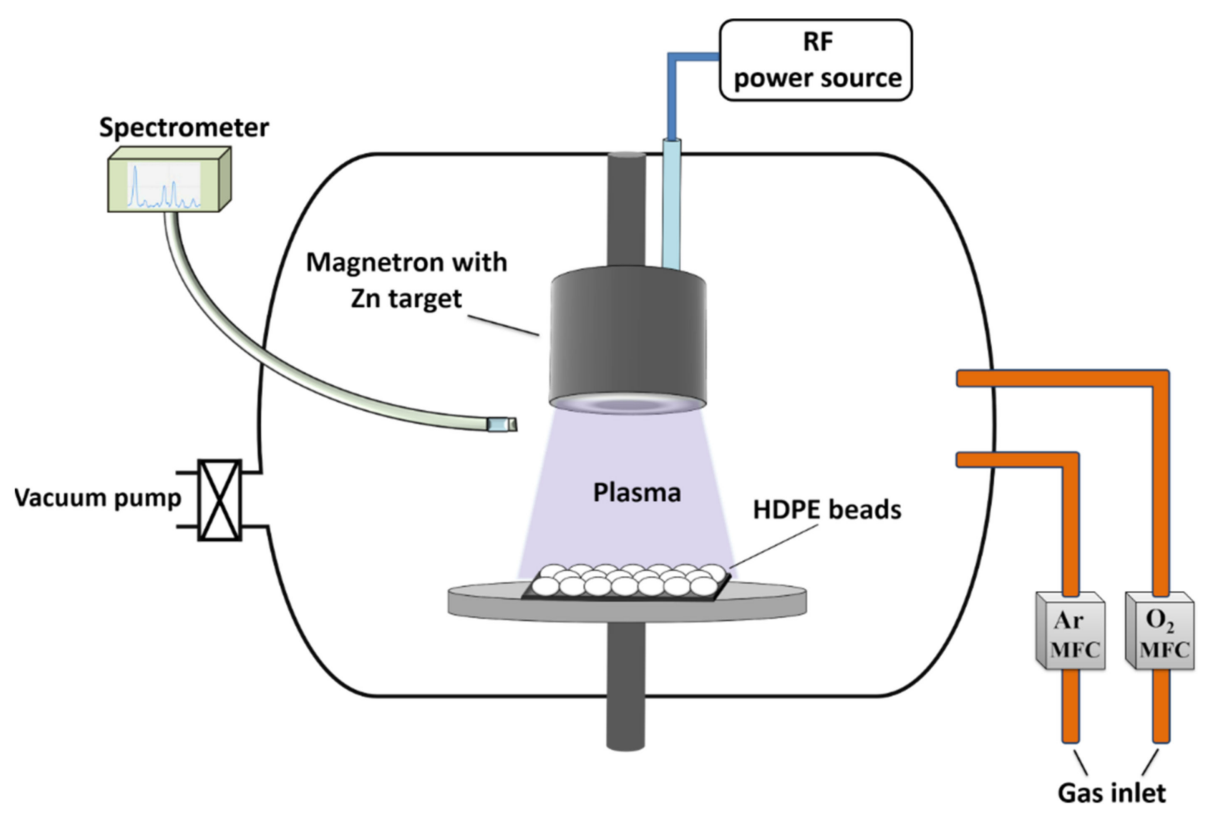

Figure 1. Experimental scheme for the deposition of $\mathrm{ZnO}$ films on the HDPE beads.

\subsection{Characterisation}

The crystal structure of deposited $\mathrm{ZnO}$ film on the HDPE beads with and without $\mathrm{Ni}$ underlayer was characterised using an X-ray diffractometer (XRD, Bruker D8, Hamburg, Germany) operating with $\mathrm{Cu} \mathrm{K} \alpha$ radiation (theta-theta configuration) in the $2 \Theta$ range of $25-70^{\circ}$ and at the measurement step size of $0.01^{\circ}$. The crystallite size was calculated by Topas 6.0 software, using the Scherrer equation with Lorentzian deconvolution. The surface morphology of the samples was measured by scanning electron microscope secondary electron detector (SEM, Hitachi S3400N, Tokyo, Japan). The elemental mapping analysis was performed using an energy dispersive X-ray spectroscope (EDS, Bruker Quad 5040, Hamburg, Germany). X-ray photoelectron spectroscope (XPS, PHI 5000 Versaprobe, Boston, MA, USA) was used for surface elemental and chemical bond analysis. The XPS analysis was performed using the following parameters: monochromated $1486.6 \mathrm{eV}$ Al radiation, 12.5 $\mathrm{W}$ beam power, $50 \mu \mathrm{m}$ beam size, and $45^{\circ}$ measurement angle. The optical bandgap of $\mathrm{ZnO}$ film was evaluated using an additional sample where $\mathrm{ZnO}$ film was deposited on a borosilicate glass substrate. Deposition conditions were kept the same as forming $\mathrm{ZnO}$ on HDPE beads. The Tauc plot calculation was applied for bandgap evaluation using obtained transmittance spectra, which were measured by an ultraviolet-visible (UV-VIS) spectrophotometer (Jasco V-650, Tokyo, Japan). The results revealed that obtained bandgap was about $3.08 \mathrm{eV}$, which is a significantly lower value, compared with the theoretical $\mathrm{ZnO}$ bandgap.

\subsection{Bacteria Inactivation and Infectivity of Bacteriophages \\ 2.3.1. Bacteria Cultivation}

For bacteria cultivation, 1-3 colony-forming units of Salmonella enterica ser. Typhimurium SL1344 (Gram-negative, Institute of Food and Health, University College Dublin, Ireland) and Micrococcus Luteus (Gram-positive, Institute of Biosciences, Vilnius University, Vilnius, Lithuania) were inoculated in $10 \mathrm{~mL}$ of fresh LB medium and incubated at $37^{\circ} \mathrm{C}$ for $18-20 \mathrm{~h}$ with shaking of $220 \mathrm{rpm}$. After incubation, the overnight culture was diluted in $50 \mathrm{~mL}$ of fresh LB medium, to obtain 0.2 of $\mathrm{OD}_{600}$, and incubated for about $2.5 \mathrm{~h}$ (for S. Typhimurium) and $3.5 \mathrm{~h}$ (for M. Luteus), to reach $0.8-1$ of $\mathrm{OD}_{600}$. The obtained suspension was centrifuged at $3000 \times g$ for $10 \mathrm{~min}$ at $4{ }^{\circ} \mathrm{C}$ temperature (Heraeus ${ }^{\mathrm{TM}}$ Megafuge $^{\mathrm{TM}} 16 \mathrm{R}$, Thermo Scientific, Bremen, Germany) and resuspended in $400 \mu \mathrm{L}$ of LB medium. 


\subsubsection{Bacteria Inactivation Test}

HDPE beads coated by $\mathrm{ZnO}$ were kept in the dark before the experiment. Tests of the viability of bacteria were carried out in $15 \mathrm{~mL}$ of phosphate-buffered saline (PBS) solution (Roth, Karlsruhe, Germany) in thermostated vessels with stirring ( $333 \mathrm{rpm})$ at $22{ }^{\circ} \mathrm{C}$. Before adding mixtures of bacteria, $1 \mathrm{~g}$ of HDPE beads coated by $\mathrm{ZnO}$ was activated for 15 min under visible-light irradiation (Solis-3C, $5700 \mathrm{~K}$, wavelength range of approximately 400-800 nm, Thorlabs, Dachau, Germany) at $65 \mathrm{~mW} / \mathrm{cm}^{2}$. During the experiments, the concentration of S. Typhimurium and M. Luteus was 0.00001 and 0.00009 of $\mathrm{OD}_{600}$, respectively. After $2.5 \mathrm{~h}$ of treatment by visible-light irradiation $\left(65 \mathrm{~mW} / \mathrm{cm}^{2}\right), 250 \mu \mathrm{L}$ of the sample was taken from the vessel and diluted 5 times. Bacteria viability tests were performed by a spread-plate technique using $50 \mu \mathrm{L}$ of the diluted sample which were spread by glass beads on LB-Agar in a Petri dish (Copacabana Method, see [52]). The viability of S. Typhimurium was assessed after $18-22 \mathrm{~h}$ of incubation at $37^{\circ} \mathrm{C}$ without agitation and of M. luteus, after 36-44 h.

\subsubsection{Treatment of Bacteriophages}

During the investigation, two types of bacteriophages were used-PRD1 and T4-which hosts are S. enterica DS88 and E. coli DH5 $\alpha$, respectively. The experimental conditions were the same as performing the bacteria inactivation test. However, the mass of HDPE beads coated by $\mathrm{ZnO}$ was $2 \mathrm{~g}$ when mixtures of bacteriophages were used and $1 \mathrm{~g}$ when using separate suspensions. The concentration of bacteriophages was $1 \times 10^{4}(\mathrm{pfu} / \mathrm{mL})$. After $1 \mathrm{~h}$ of treatment by visible-light irradiation, $100 \mu \mathrm{L}$ of bacteriophage suspension was taken from the vessel and diluted 10 times. Afterwards, $100 \mu \mathrm{L}$ of obtained suspension was poured into an overnight culture of the host's bacteria suspension. Finally, the suspension was spread on the LB-Agar Petri dish (see the plaque-forming method in [53]). The infectivity of bacteriophages was evaluated after $22 \mathrm{~h}$ of incubation at $37^{\circ} \mathrm{C}$.

\section{Results and Discussion}

\subsection{Structural Analysis}

Phase structure of primary HDPE beads and ZnO deposited on the HDPE beads without and with $\mathrm{Ni}$ underlayer was examined by $\mathrm{X}$-ray diffraction technique (Figure 2). XRD pattern of primary HDPE beads is presented in Figure 2a. The size of beads used in this study was $2-4 \mathrm{~mm}$. The XRD data were collected from the surface of HDPE beads which is exceptionally rough for XRD and, unlike the flat sample, causes the broadening in the peaks. However, all of the peaks matched the structure of the high-density polyethylene $\left(\left(\mathrm{C}_{2} \mathrm{H}_{4}\right)_{\mathrm{n}}\right)$ which corresponds to the standard JCPDS card number 00-060-0984. Any other crystalline impurities were not detected.

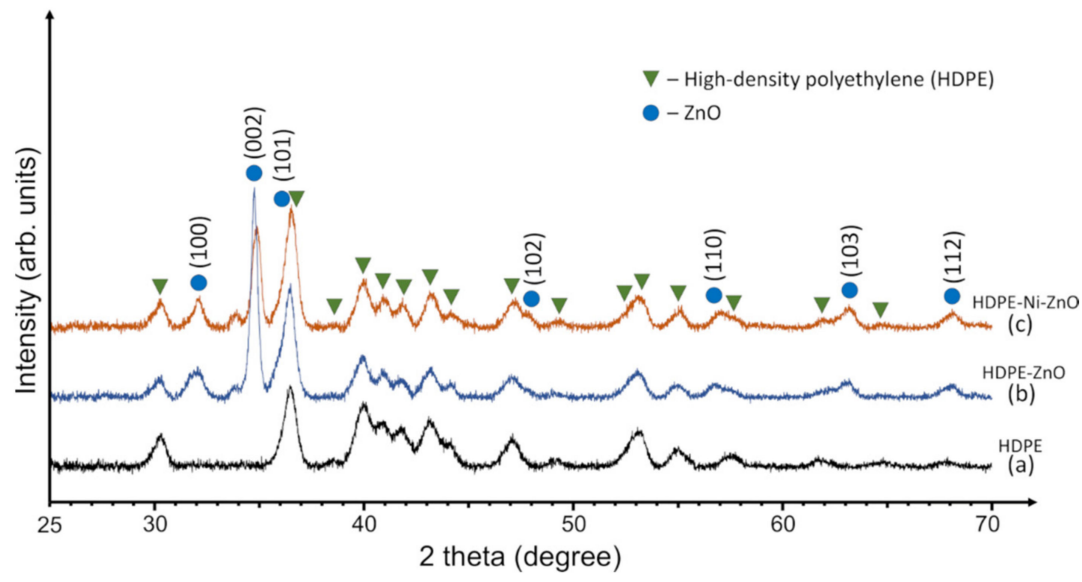

Figure 2. XRD patterns of (a) primary HDPE beads, (b) ZnO deposited on the HDPE beads without $\mathrm{Ni}$ underlayer, and (c) $\mathrm{ZnO}$ deposited on the HDPE beads with Ni underlayer. 
The XRD results of $\mathrm{ZnO}$ deposited on the HDPE beads without and with Ni layer (Figure 2b,c, respectively) correlated well with the hexagonal wurtzite structure of $\mathrm{ZnO}$ (JCPDS card number 01-070-8070). The characteristic diffraction peaks of $\mathrm{ZnO}$ at $2 \Theta=31.7^{\circ}$, $34.5^{\circ}, 36.2^{\circ}, 47.5^{\circ}, 56.6^{\circ}, 62.9^{\circ}$, and $68.0^{\circ}$ correspond to (100), (002), (101), (102), (110), (103), and (112) crystal planes, respectively. This is totally consistent with the XRD analysis of $\mathrm{ZnO}$ reported in the literature [54-56]. It can be observed that the predominant crystal plane is (002), commonly found in the films deposited by sputtering technique due to the minimum surface energy of (002) which results in higher crystallites orientation rate along the c-axis [57-59]. The average crystallite sizes were $28 \mathrm{~nm}$ and $21 \mathrm{~nm}$ for the $\mathrm{ZnO}$ (002) deposited on HDPE beads without Ni and with Ni underlayer, respectively. Similar behaviour was found in the literature when various additional impurities tend to reduce the crystallite size slightly $[23,60,61]$.

In the case of HDPE beads with Ni underlayer, XRD scanning did not detect any peaks attributed to nickel (Figure 2c). Presumably, Ni may have been deposited in an amorphous state, or the intensity of $\mathrm{Ni}$ peaks is too low to be visible in the spectrum. However, the $\mathrm{XRD}$ results confirm the successful deposition of crystalline $\mathrm{ZnO}$ onto a floatable substrate.

\subsection{Morphology and Elemental Mapping Analysis}

The surface morphology of the floating $\mathrm{ZnO}-\mathrm{HDPE}$ photocatalyst was investigated by SEM as shown in Figure 3. First of all, the images indicated that the surface of HDPE support was successfully deposited by $\mathrm{ZnO}$ film without significant defects, scarcities, or detachments of $\mathrm{ZnO}$ film. Still, deposited $\mathrm{ZnO}$ film results in roughening of the relatively smooth HDPE bead surface. These observations can be applied for both types of photocatalyst despite the existence of Ni underlayer (Figure 3a,b).
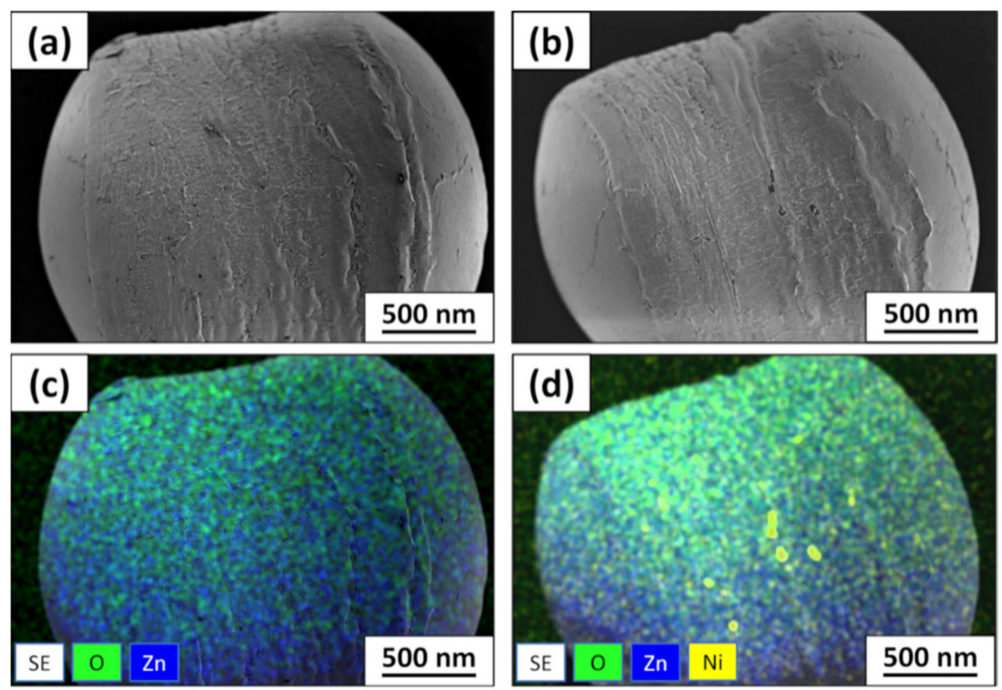

Figure 3. SEM views and EDS mapping of $\mathrm{ZnO}$ deposited on HDPE surface (a-c) without $\mathrm{Ni}$ underlayer and $(\mathbf{b}-\mathbf{d})$ with Ni underlayer, respectively.

The elemental mapping confirmed the relatively uniform distribution of $\mathrm{Zn}$ and $\mathrm{O}$ elements across the HDPE beads surface in both cases. Figure $3 \mathrm{~d}$ represents photocatalyst with Ni underlayer, while only a few Ni clusters can be observed. This is related to the $\mathrm{ZnO}$ film thickness, which is about 4-5 $\mu \mathrm{m}$ and technological limitations of EDS determine that $\mathrm{Ni}$ can be seen only in the areas with thinner $\mathrm{ZnO}$ film, its absence or cracks. In general, the surface morphology and elemental mapping analysis showed that Ni underlayer does not have a significant influence on $\mathrm{ZnO}$ film surface characteristics deposited on HDPE beads.

\subsection{XPS Results}

Elemental surface analysis of $\mathrm{ZnO}$ film deposited on the HDPE beads without and with $\mathrm{Ni}$ underlayer is presented in Figure 4. In both cases, the detected elements were 
carbon $(\mathrm{C})$, oxygen $(\mathrm{O})$, and zinc $(\mathrm{Zn})$, without any unwanted impurities. Quantification of these elements demonstrated similar results for both samples (inserted table in Figure 4). Such an amount of carbon is observed due to exposure of samples to the ambient air. After $\mathrm{ZnO}$ film deposition, samples were taken out from the vacuum chamber and handled in the air which caused the formation of a thin adventitious carbon/hydrocarbon (and/or hydroxyl species) layer [62]. The Ni underlayer is immobilised under a thick layer of $\mathrm{ZnO}$. Therefore, the XPS did not detect any peaks of $\mathrm{Ni}$ since it is a surface-sensitive measurement technique.

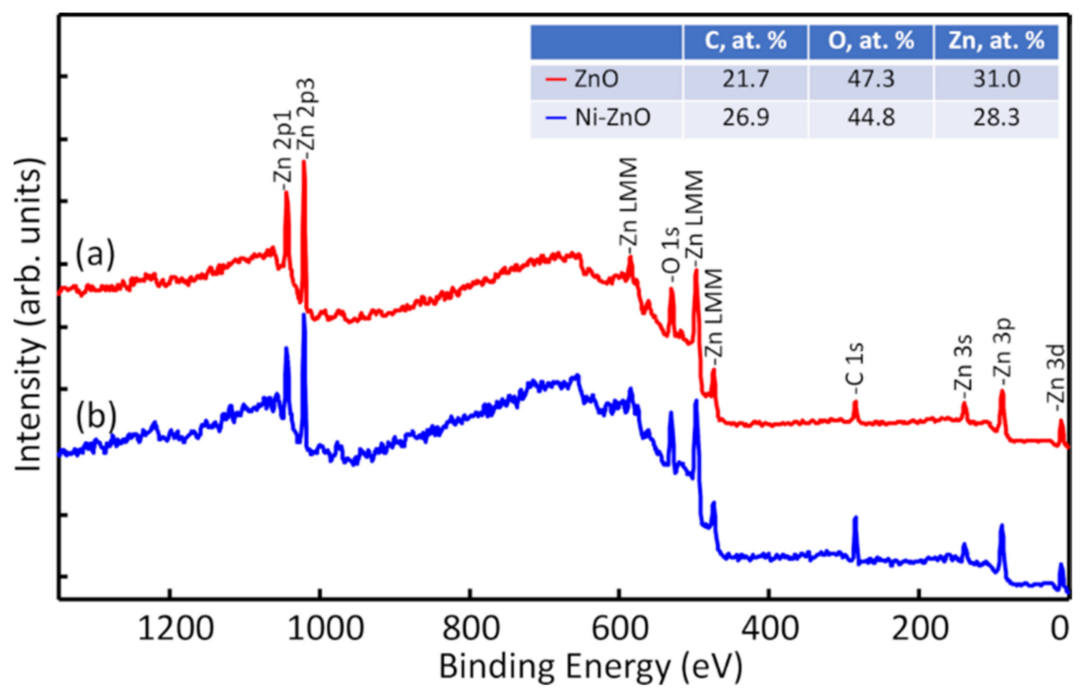

Figure 4. XPS survey spectra of $\mathrm{ZnO}$ deposited on the HDPE beads (a) without Ni and (b) with Ni underlayer.

The surface chemical bond analysis of the $\mathrm{ZnO}$ film deposited on the HDPE beads without and with Ni underlayer was performed by high-resolution XPS scans for Zn $2 p$ and $\mathrm{O} 1$ s regions (Figure 5a,b, respectively). However, the Ni underlayer did not affect the chemical structure (oxidation state) of the surface because both samples showed nearly identical spectra. Zn $2 \mathrm{p}$ spectrum consisted of two main components of $\mathrm{Zn} 2 \mathrm{p}_{3 / 2}$ and $\mathrm{Zn} 2 \mathrm{p}_{1 / 2}$ positioned at 1021.8 and $1044.9 \mathrm{eV}$, respectively (Figure 5a). According to other studies, these binding energies and separation of $23.1 \mathrm{eV}$ between two peaks represent the $\mathrm{Zn}^{2+}$ ions of $\mathrm{ZnO}$ lattice ( $\mathrm{Zn}-\mathrm{O}$ bonds) [63-65]. The $\mathrm{O}$ 1s electron spectrum was deconvoluted into 3 peaks (Figure $5 \mathrm{~b}$ ). The major one at about $530.8 \mathrm{eV}$ was assigned to the $\mathrm{O}^{2-}$ oxidation state which also confirmed the formation of $\mathrm{Zn}-\mathrm{O}$ bonds in the wurtzite structure. The shoulder peaks (at the higher energies) can be attributed to the oxygen atoms in $\mathrm{C}-\mathrm{O}, \mathrm{C}=\mathrm{O}$ bonds, or even hydroxyl groups, due to surface contamination by species and moisture existing in the air [66].
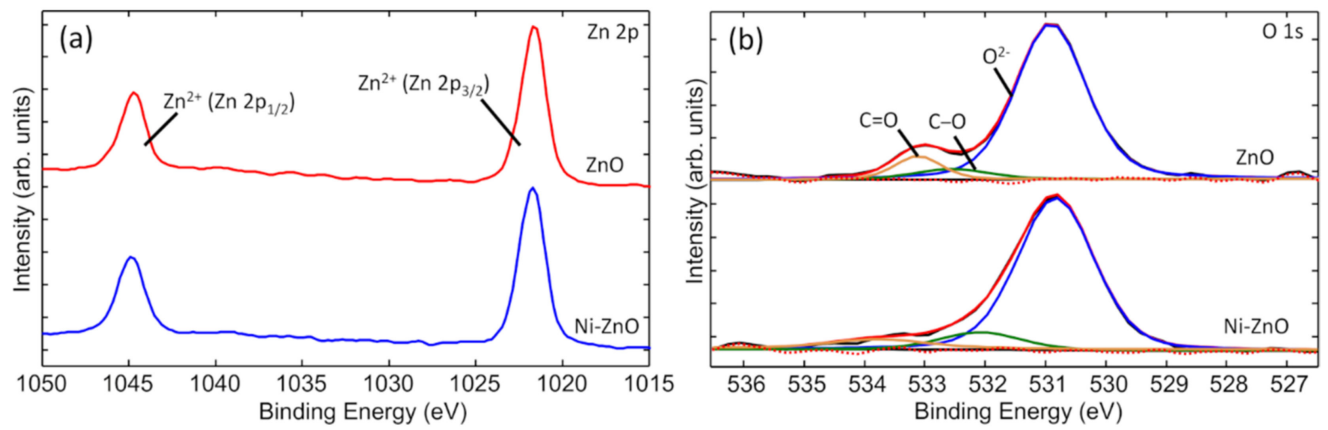

Figure 5. Comparison of (a) $\mathrm{Zn} 2 \mathrm{p}$ and (b) $\mathrm{O}$ 1s electron spectra for $\mathrm{ZnO}$ deposited on the HDPE beads without $\mathrm{Ni}(\mathrm{ZnO})$ and with $\mathrm{Ni}$ underlayer $(\mathrm{Ni}-\mathrm{ZnO})$. 


\subsection{Inactivation of the Mixture of M. Luteus and S. Typhimurium Bacteria}

In this study, the bactericidal effect of the floatable photocatalyst was evaluated. The viability of M. Luteus and S. Typhimurium separately and a mixture of these two types of bacteria were tested under visible-light irradiation using $\mathrm{ZnO}$ film deposited on the HDPE beads without and with Ni underlayer (Figure 6).
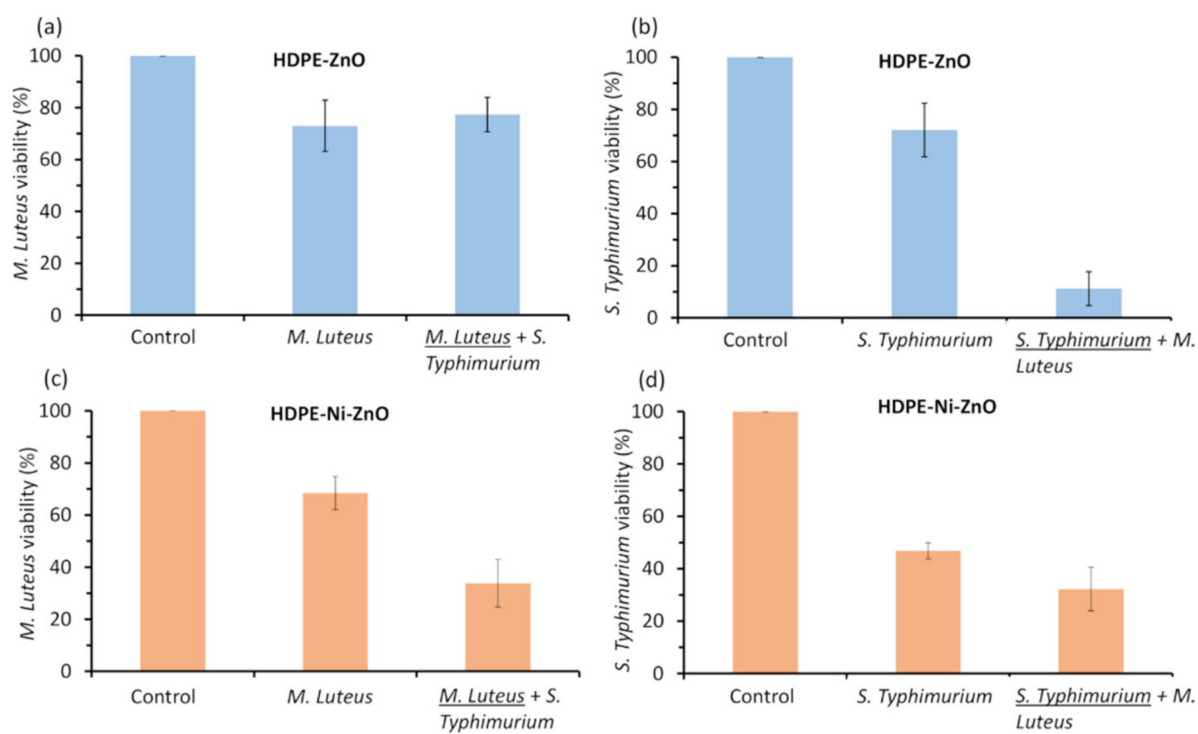

Figure 6. Photocatalytic inactivation of separate M. Luteus and S. Typhimurium bacteria and their mixture under visible-light irradiation for $2.5 \mathrm{~h}$ : (a) viability of $M$. Luteus alone and in the mixture with S. Typhimurium using $\mathrm{ZnO}$ film deposited on the HDPE beads without Ni underlayer; (b) viability of S. Typhimurium alone and in the mixture with M. Luteus using $\mathrm{ZnO}$ film deposited on the HDPE beads without Ni underlayer; (c) viability of $M$. Luteus alone and in the mixture with S. Typhimurium using $\mathrm{ZnO}$ film deposited on the HDPE beads with Ni underlayer; (d) viability of S. Typhimurium alone and in the mixture with M. Luteus using $\mathrm{ZnO}$ film deposited on the HDPE beads with Ni underlayer. The length of the error bars is the standard deviation of each measurement.

Prior to the experiments, blank tests were performed without photocatalyst under visible light irradiation which showed that viability of bacteria at most decreased by approximately $20 \%$. Meanwhile, the viability of bacteria with photocatalyst in the dark was not affected. Photocatalyst without Ni underlayer reduced the viability of $M$. Luteus approximately by about $25 \%$ when irradiated by visible light separately or in a mixture with S. Typhimurium (Figure 6a). The result was slightly better than the one obtained during the blank test without photocatalyst. On the other hand, after irradiation of S. Typhimurium bacteria the viability decreased by $89 \%$ when it was in the mixture with $M$. Luteus and only $28 \%$ while irradiating the suspension of S. Typhimurium individually (Figure $6 \mathrm{~b}$ ). Interestingly, the inactivation of separate bacteria showed similar values, but the results significantly differed when comparing bacteria mixtures.

The photocatalyst with Ni underlayer showed greater efficiency, compared with HDPE-coated by ZnO film without Ni underlayer. Presumably, Ni creates a synergistic effect on photocatalyst performance. Although the Ni metal underlayers were used in our case, it is known that transition metal dopants can introduce inter-bands in the photocatalyst structure and enhance the charge separation by suppressing the electron-hole recombination. $[67,68]$. Due to the thick $\mathrm{ZnO}$ film and limited measurement depth, the XPS and XRD analysis methods did not detect Ni underlayer. Nevertheless, it cannot be excluded that some $\mathrm{Ni}$ additives might be diffused in random parts of the $\mathrm{ZnO}$ structure. Presumably, the dopants can increase the concentration of oxygen vacancies in the structure which further enhances the bactericidal effect of the photocatalyst [69]. It was reported that transition metal-doped $\mathrm{ZnO}$ particles have a synergistic effect on photocatalytic and 
antibacterial performances $[15,47,70]$. On the other hand, the EDS mapping showed some spots of $\mathrm{Ni}$ in the areas where $\mathrm{ZnO}$ film is thinner or cracked. Accordingly, these $\mathrm{Ni}$ spots can partially contribute to the reduction in bacteria viability by causing oxidative stress due to the direct interaction with bacteria [71]. The viability of $M$. Luteus was reduced by $32 \%$ after irradiating a suspension individually and by $66 \%$ when in the mixture with $S$. Typhimurium (Figure 6c). Meanwhile, the S. Typhimurium bacteria were more sensitive than $M$. Luteus after individual treatment under visible light. The viability of S. Typhimurium decreased by $53 \%$ when bacteria were tested alone. However, obtained results were nearly the same as with $M$. Luteus after irradiation of bacteria in the mixture (the remaining viability was $32 \%$ ) (Figure 6d).

Obtained results suggest that in the case of bacteria mixtures, the viability of bacteria depends on the bactericidal efficiency as well as on the interaction between different types of bacteria. For example, it is known that Gram-positive bacteria such as Staphylococcus aureus inhibit the growth of Salmonella [72]. Therefore, the increased bactericidal effect of photocatalyst against S. Typhimurium bacteria in the mixture with M. Luteus (Figure 6b) could be due to the negative interaction between two species of bacteria.

\subsection{Inactivation of the Mixture of PRD1 and T4 Bacteriophages}

$\mathrm{ZnO}$ photocatalyst alone (in the dark) did not affect or lower the infectivity of bacteriophages. On the other hand, the blank test of visible light irradiation on bacteriophages without the photocatalyst showed that the infectivity decreased by about $2-7 \%$. Results showed that bacteriophages seem more resistant to light than bacteria. ZnO-coated HDPE beads without Ni underlayer reduced the infectivity of $P R D 1$ phage by $12 \%$, while in the case of mixture with T4, by $20 \%$ after irradiation under visible light (Figure $7 \mathrm{a}$ ). Moreover, the infectivity of $T 4$ decreased by $38 \%$ and $47 \%$ after irradiation of $T 4$ alone and in the mixture with $P R D 1$, respectively. To summarise, this investigation demonstrated that visible-light-activated $\mathrm{ZnO}$ photocatalyst (without $\mathrm{Ni}$ ) had a more noticeable effect on the bacteriophage mixtures than on bacteriophages alone.
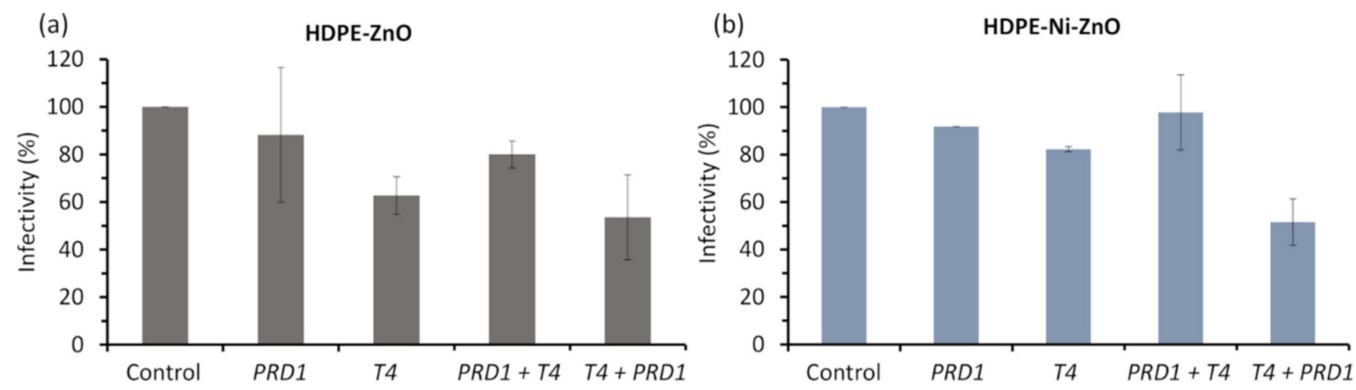

Figure 7. Infectivity of separate $P R D 1$ and $T 4$ bacteriophages and their mixture under visible-light irradiation for $1 \mathrm{~h}$ using $\mathrm{ZnO}$ film deposited on the HDPE beads (a) without Ni underlayer and (b) with Ni underlayer. The length of the error bars is the standard deviation of each measurement.

The obtained results were just slightly different while testing the $\mathrm{ZnO}$-coated HDPE beads with Ni underlayer (Figure $7 \mathrm{~b}$ ). The infectivity of the PRD1 phage decreased by about $10 \%$, while the photocatalyst was inefficient against PRD1 in the mixture with T4 phage. The infectivity was reduced by $18 \%$ and almost $50 \%$ after treatment of $T 4$ alone and in the mixture with PRD1, respectively. Consequently, the PRD1 bacteriophage is sufficiently resistant to $\mathrm{ZnO}$ photocatalyst deposited on the HDPE beads with Ni underlayer, and the sensitivity of T4 phage strongly increased when treated in mixture with the phage of PRD1. In both cases, the $\mathrm{ZnO}$-based floating photocatalyst affects bacteriophages less than bacteria (Figure 6). It is known that bacteriophages (as viruses) are more resistant to light irradiation or stress effects than bacterial cells [73]. 


\section{Conclusions}

In the current study, HDPE beads with and without Ni underlayer were used as floatable substrates for the $\mathrm{ZnO}$ photocatalyst which was successfully deposited via reactive magnetron sputtering technique. In both cases, the XRD analysis revealed the formation of a hexagonal wurtzite $\mathrm{ZnO}$ structure with a predominant crystal plane of (002) on the surface of HDPE beads. Such crystal orientation is quite common using magnetron sputtering due to minimum surface energy. Nickel peaks were not detected by XRD. The surface chemical bond analysis of the $\mathrm{ZnO}$ film deposited on the HDPE beads without and with $\mathrm{Ni}$ underlayer confirmed the formation of $\mathrm{Zn}-\mathrm{O}$ bonds in the wurtzite structure. Any additional elements except carbon, oxygen, and zinc were not detected by XPS. Although the morphology measurement showed a bit rough surface, any significant defects or detachments of $\mathrm{ZnO}$ film were not detected. Additionally, elemental mapping presented evenly distributed $\mathrm{Zn}$ and $\mathrm{O}$ across the surface of HDPE beads either without Ni or with $\mathrm{Ni}$ underlayer. $\mathrm{Ni}$ was observed only in the areas where $\mathrm{ZnO}$ film is possibly thinner or mechanically cracked.

Moreover, after testing under visible-light irradiation, it was verified that $\mathrm{ZnO}$-coated HDPE beads with Ni underlayer (compared with without $\mathrm{Ni}$ ) had an improved performance in the inactivation of bacteria alone and their mixture. The viability of $M$. Luteus and S. Typhimurium was reduced by $32 \%$ and $53 \%$, respectively, when the bacteria were tested alone using photocatalyst with Ni underlayer. Meanwhile, the nickel-free photocatalyst decreased the viability by $25 \%$ and $28 \%$, respectively. The viability of bacteria in the mixture demonstrated even better results. Surprisingly, the best result was achieved using $\mathrm{ZnO}$-coated HDPE beads without Ni underlayer which reduced the viability of $S$. Typhimurium in the mixture with M. Luteus by $89 \%$. Such increased bactericidal effect could be measured due to the negative interaction of different types of bacteria on each other. Investigation of infectivity of separate PRD1 and T4 bacteriophages and their mixture did not show a considerable difference between the $\mathrm{ZnO}$ photocatalysts without $\mathrm{Ni}$ and with Ni underlayer. However, it has been observed that a $T 4$ phage undergoes a greater photocatalyst-induced inactivation.

Author Contributions: Conceptualisation and supervision, M.L.; methodology, M.U. and S.V.; investigation, S.S., S.T., S.V., M.U. and E.D.; writing—original draft preparation, M.U., S.V. and S.S.; writing-review and editing, S.V., M.U. and M.L.; visualisation, S.T., M.U. and S.V. All authors have read and agreed to the published version of the manuscript.

Funding: This research is funded by the European Social Fund according to the activity 'Improvement of researchers' qualification by implementing world-class R\&D projects' of Measure No. 09.3.3LMT-K-712, project 'Investigation of the application of $\mathrm{TiO}_{2}$ and $\mathrm{ZnO}$ for the visible light assisted photocatalytical disinfection of the biologically contaminated water' (09.3.3-LMT-K-712-01-0175).

Institutional Review Board Statement: Not applicable.

Informed Consent Statement: Not applicable.

Data Availability Statement: Data are contained within the article.

Acknowledgments: The authors express gratitude to Rimantas Daugelavicius for his input in conceptualisation and supervision, and Mindaugas Aikas, Rolandas Uscila, Neringa Kuliesiene, and Deimante Vasiliauske for their valuable input in the preparation and testing of the samples.

Conflicts of Interest: The authors declare no conflict of interest.

\section{References}

1. Baaloudj, O.; Assadi, I.; Nasrallah, N.; El Jery, A.; Khezami, L.; Assadi, A.A. Simultaneous removal of antibiotics and inactivation of antibiotic-resistant bacteria by photocatalysis: A review. J. Water Process Eng. 2021, 42, 102089. [CrossRef]

2. Alrumman, S.A.; El-kott, A.F.; Keshk, S.M.A.S. Water Pollution: Source and Treatment Water Pollution: Source \& Treatment. Am. J. Environ. Eng. 2016, 6, 88-98. 
3. Jiménez-Tototzintle, M.; Ferreira, I.J.; da Silva Duque, S.; Guimarães Barrocas, P.R.; Saggioro, E.M. Removal of contaminants of emerging concern (CECs) and antibiotic resistant bacteria in urban wastewater using $\mathrm{UVA} / \mathrm{TiO}_{2} / \mathrm{H}_{2} \mathrm{O}_{2}$ photocatalysis. Chemosphere 2018, 210, 449-457. [CrossRef] [PubMed]

4. Hwangbo, M.; Claycomb, E.C.; Liu, Y.; Alivio, T.E.G.; Banerjee, S.; Chu, K.H. Effectiveness of zinc oxide-assisted photocatalysis for concerned constituents in reclaimed wastewater: 1,4-Dioxane, trihalomethanes, antibiotics, antibiotic resistant bacteria (ARB), and antibiotic resistance genes (ARGs). Sci. Total Environ. 2019, 649, 1189-1197. [CrossRef]

5. $\quad$ Biancullo, F.; Moreira, N.F.F.; Ribeiro, A.R.; Manaia, C.M.; Faria, J.L.; Nunes, O.C.; Castro-Silva, S.M.; Silva, A.M.T. Heterogeneous photocatalysis using UVA-LEDs for the removal of antibiotics and antibiotic resistant bacteria from urban wastewater treatment plant effluents. Chem. Eng. J. 2019, 367, 304-313. [CrossRef]

6. Manaia, C.M.; Rocha, J.; Scaccia, N.; Marano, R.; Radu, E.; Biancullo, F.; Cerqueira, F.; Fortunato, G.; Iakovides, I.C.; Zammit, I.; et al. Antibiotic resistance in wastewater treatment plants: Tackling the black box. Environ. Int. 2018, 115, 312-324. [CrossRef]

7. Zhang, C.; Xu, L.; Mou, X.; Xu, H.; Liu, J.; Miao, Y.; Wang, X.C.; Li, X. Characterization and evolution of antibiotic resistance of Salmonella in municipal wastewater treatment plants. J. Environ. Manag. 2019, 251, 109547. [CrossRef]

8. Di Mauro, A.; Fragalà, M.E.; Privitera, V.; Impellizzeri, G. ZnO for application in photocatalysis: From thin films to nanostructures Mater. Sci. Semicond. Process. 2017, 69, 44-51. [CrossRef]

9. Liu, J.; Wang, Y.; Ma, J.; Peng, Y.; Wang, A. A review on bidirectional analogies between the photocatalysis and antibacterial properties of ZnO. J. Alloys Compd. 2019, 783, 898-918. [CrossRef]

10. Ferreira, S.H.; Morais, M.; Nunes, D.; Oliveira, M.J.; Rovisco, A.; Pimentel, A.; Águas, H.; Fortunato, E.; Martins, R. High UV and Sunlight Photocatalytic Performance of Porous ZnO Nanostructures Synthesized by a Facile and Fast Microwave Hydrothermal Method. Materials 2021, 14, 2385. [CrossRef]

11. Chinnathambi, A. Synthesis and characterization of spinel $\mathrm{FeV}_{2} \mathrm{O}_{4}$ coupled $\mathrm{ZnO}$ nanoplates for boosted white light photocatalysis and antibacterial applications. J. Alloys Compd. 2022, 890, 161742. [CrossRef]

12. Saravanan, R.; Sacari, E.; Gracia, F.; Khan, M.M.; Mosquera, E.; Gupta, V.K. Conducting PANI stimulated ZnO system for visible light photocatalytic degradation of coloured dyes. J. Mol. Liq. 2016, 221, 1029-1033. [CrossRef]

13. Sevastaki, M.; Papadakis, V.M.; Romanitan, C.; Suchea, M.P.; Kenanakis, G. Photocatalytic properties of eco-friendly zno nanostructures on 3d-printed polylactic acid scaffolds. Nanomaterials 2021, 11, 168. [CrossRef]

14. Samadi, M.; Zirak, M.; Naseri, A.; Khorashadizade, E.; Moshfegh, A.Z. Recent progress on doped ZnO nanostructures for visible-light photocatalysis. Thin Solid Films 2016, 605, 2-19. [CrossRef]

15. Qi, K.; Xing, X.; Zada, A.; Li, M.; Wang, Q.; Liu, S.; Lin, H.; Wang, G. Transition metal doped ZnO nanoparticles with enhanced photocatalytic and antibacterial performances: Experimental and DFT studies. Ceram. Int. 2020, 46, 1494-1502. [CrossRef]

16. Wei, X.; Liu, H.; Li, T.; Jiang, Z.; Hu, W.; Niu, Q.; Chen, J. Three-dimensional flower heterojunction g- $\mathrm{C}_{3} \mathrm{~N}_{4} / \mathrm{Ag} / \mathrm{ZnO}$ composed of ultrathin nanosheets with enhanced photocatalytic performance. J. Photochem. Photobiol. A Chem. 2020, 390, 112342. [CrossRef]

17. Gotipamul, P.P.; Vattikondala, G.; Rajan, K.D.; Khanna, S.; Rathinam, M.; Chidambaram, S. Impact of piezoelectric effect on the heterogeneous visible photocatalysis of $\mathrm{g}_{-} \mathrm{C}_{3} \mathrm{~N}_{4} / \mathrm{Ag} / \mathrm{ZnO}$ tricomponent. Chemosphere 2022, 287, 132298. [CrossRef]

18. Macías-Sánchez, J.J.; Hinojosa-Reyes, L.; Caballero-Quintero, A.; de la Cruz, W.; Ruiz-Ruiz, E.; Hernández-Ramírez, A.; Guzmán-Mar, J.L. Synthesis of nitrogen-doped ZnO by sol-gel method: Characterization and its application on visible photocatalytic degradation of 2,4-D and picloram herbicides. Photochem. Photobiol. Sci. 2015, 14, 536-542. [CrossRef]

19. Samadi, M.; Shivaee, H.A.; Zanetti, M.; Pourjavadi, A.; Moshfegh, A. Visible light photocatalytic activity of novel MWCNT-doped ZnO electrospun nanofibers. J. Mol. Catal. A Chem. 2012, 359, 42-48. [CrossRef]

20. Poongodi, G.; Mohan Kumar, R.; Jayavel, R. Influence of S doping on structural, optical and visible light photocatalytic activity of ZnO thin films. Ceram. Int. 2014, 40, 14733-14740. [CrossRef]

21. Mittal, M.; Sharma, M.; Pandey, O.P. UV-Visible light induced photocatalytic studies of Cu doped ZnO nanoparticles prepared by co-precipitation method. Sol. Energy 2014, 110, 386-397. [CrossRef]

22. Jiang, Y.; Xiong, Z.; Huang, J.; Yan, F.; Yao, G.; Lai, B. Effective E. coli inactivation of core-shell ZnO@ZIF-8 photocatalysis under visible light synergize with peroxymonosulfate: Efficiency and mechanism. Chin. Chem. Lett. 2022, 33, 415-423. [CrossRef]

23. Mirzaeifard, Z.; Shariatinia, Z.; Jourshabani, M.; Rezaei Darvishi, S.M. ZnO Photocatalyst Revisited: Effective Photocatalytic Degradation of Emerging Contaminants Using S-Doped ZnO Nanoparticles under Visible Light Radiation. Ind. Eng. Chem. Res. 2020, 59, 15894-15911. [CrossRef]

24. Poliukhova, V.; Cho, S.; Orlov, A. ZnO-NiO Composites for Photocatalysis of Methylene Blue. In Proceedings of the 2018 IEEE 38th International Conference on Electronics and Nanotechnology (ELNANO), Kyiv, Ukraine, 24-26 April 2018; pp. 191-196.

25. Wang, Y.; Liu, T.; Huang, Q.; Wu, C.; Shan, D. Synthesis and their photocatalytic properties of Ni-doped ZnO hollow microspheres. J. Mater. Res. 2016, 31, 2317-2328. [CrossRef]

26. Moorthy, K.; Inbanathan, S.S.R.; Gopinathan, C.; Lalla, N.P.; Alghamdi, A.A.; Kumar, R.; Rani Rosaline, D.; Umar, A. Ni-Doped ZnO Thin Films: Deposition, Characterization and Photocatalytic Applications. J. Nanosci. Nanotechnol. 2021, 21, 1560-1569. [CrossRef]

27. Zhao, J.; Wang, L.; Yan, X.; Yang, Y.; Lei, Y.; Zhou, J.; Huang, Y.; Gu, Y.; Zhang, Y. Structure and photocatalytic activity of Ni-doped $\mathrm{ZnO}$ nanorods. Mater. Res. Bull. 2011, 46, 1207-1210. [CrossRef] 
28. Varnagiris, S.; Urbonavičius, M.; Sakalauskaitè, S.; Demikyte, E.; Tuckute, S. Floating carbon-doped TiO ${ }_{2}$ photocatalyst with metallic underlayers investigation for polluted water treatment under visible-light irradiation. Catalysts 2021, 11, 1454. [CrossRef]

29. Darkhosh, F.; Lashanizadegan, M.; Mahjoub, A.R.; Cheshme Khavar, A.H. One pot synthesis of $\mathrm{CuFeO}_{2} @$ expanding perlite as a novel efficient floating catalyst for rapid degradation of methylene blue under visible light illumination. Solid State Sci. 2019, 91, 61-72. [CrossRef]

30. Nasir, A.M.; Jaafar, J.; Aziz, F.; Yusof, N.; Salleh, W.N.W.; Ismail, A.F.; Aziz, M. A review on floating nanocomposite photocatalyst: Fabrication and applications for wastewater treatment. J. Water Process Eng. 2020, 36, 101300. [CrossRef]

31. Wang, X.; Wang, X.; Zhao, J.; Song, J.; Wang, J.; Ma, R.; Ma, J. Solar light-driven photocatalytic destruction of cyanobacteria by F-Ce- $\mathrm{TiO}_{2}$ / expanded perlite floating composites. Chem. Eng. J. 2017, 320, 253-263. [CrossRef]

32. Song, J.; Wang, X.; Ma, J.; Wang, X.; Wang, J.; Zhao, J. Visible-light-driven in situ inactivation of Microcystis aeruginosa with the use of floating g-C3N4 heterojunction photocatalyst: Performance, mechanisms and implications. Appl. Catal. B Environ. 2018, 226, 83-92. [CrossRef]

33. Wang, X.; Wang, X.; Zhao, J.; Song, J.; Zhou, L.; Wang, J.; Tong, X.; Chen, Y. An alternative to in situ photocatalytic degradation of microcystin-LR by worm-like N, P co-doped $\mathrm{TiO}_{2}$ /expanded graphite by carbon layer (NPT-EGC) floating composites. Appl. Catal. B Environ. 2017, 206, 479-489. [CrossRef]

34. Song, J.; Wang, X.; Ma, J.; Wang, X.; Wang, J.; Xia, S.; Zhao, J. Removal of Microcystis aeruginosa and Microcystin-LR using a graphitic- $\mathrm{C}_{3} \mathrm{~N}_{4} / \mathrm{TiO}_{2}$ floating photocatalyst under visible light irradiation. Chem. Eng. J. 2018, 348, 380-388. [CrossRef]

35. De Vietro, N.; Tursi, A.; Beneduci, A. Photocatalytic inactivation of Escherichia coli bacteria in water using low pressure plasma deposited $\mathrm{TiO}_{2}$ cellulose fabric. Photochem. Photobiol. Sci. 2019, 18, 2248-2258. [CrossRef]

36. Zheng, X.; Shen, Z.-P.; Cheng, C.; Shi, L.; Cheng, R.; Yuan, D.-H. Photocatalytic disinfection performance in virus and virus/bacteria system by $\mathrm{Cu}-\mathrm{TiO}_{2}$ nanofibers under visible light. Environ. Pollut. 2018, 237, 452-459. [CrossRef]

37. Moreira, N.F.F.; Narciso-da-Rocha, C.; Polo-López, M.I.; Pastrana-Martínez, L.M.; Faria, J.L.; Manaia, C.M.; Fernández-Ibáñez, P.; Nunes, O.C.; Silva, A.M.T. Solar treatment $\left(\mathrm{H}_{2} \mathrm{O}_{2}, \mathrm{TiO}_{2}-\mathrm{P} 25\right.$ and GO-TiO 2 photocatalysis, photo-Fenton) of organic micropollutants, human pathogen indicators, antibiotic resistant bacteria and related genes in urban wastewater. Water Res. 2018, 135, 195-206. [CrossRef]

38. Mecha, A.C.; Onyango, M.S.; Ochieng, A.; Momba, M.N.B. UV and solar photocatalytic disinfection of municipal wastewater: Inactivation, reactivation and regrowth of bacterial pathogens. Int. J. Environ. Sci. Technol. 2019, 16, 3687-3696. [CrossRef]

39. Brugnera, M.F.; Miyata, M.; Zocolo, G.J.; Leite, C.Q.F.; Zanoni, M.V.B. A photoelectrocatalytic process that disinfects water contaminated with Mycobacterium kansasii and Mycobacterium avium. Water Res. 2013, 47, 6596-6605. [CrossRef]

40. Zammit, I.; Vaiano, V.; Ribeiro, A.R.; Silva, A.M.T.; Manaia, C.M.; Rizzo, L. Immobilised cerium-doped zinc oxide as a photocatalyst for the degradation of antibiotics and the inactivation of antibiotic-resistant bacteria. Catalysts 2019, 9, 222. [CrossRef]

41. Zhang, C.; Li, Y.; Shuai, D.; Shen, Y.; Wang, D. Progress and challenges in photocatalytic disinfection of waterborne Viruses: A review to fill current knowledge gaps. Chem. Eng. J. 2019, 355, 399-415. [CrossRef]

42. Restifo, L.L.; Vogelbacker, H.H.; Madara, T.; Ling, S.K.; Kozinski, A.W. Effects of UV irradiation on the fate of 5bromodeoxyuridine-substituted bacteriophage T4 DNA. J. Virol. 1983, 47, 151-170. [CrossRef]

43. Urbonavicius, M.; Varnagiris, S.; Sakalauskaite, S.; Demikyte, E.; Tuckute, S.; Lelis, M. Application of Floating TiO $\mathrm{TPh}_{2} \mathrm{Photo}$ atalyst for Methylene Blue Decomposition and Salmonella typhimurium Inactivation. Catalysts 2021, 11, 794. [CrossRef]

44. Demikyte, E.; Sakalauskaite, S.; Kuliesiene, N.; Urbonavicius, M.; Varnagiris, S. Ni Underlayer Effect for the Structure Development and Visible Light Photocatalytic Efficiency of Carbon-Doped $\mathrm{TiO}_{2}$ Film. Sci. J. Riga Tech. Univ. Environ. Clim. Technol. 2021, 25, 1032-1042. [CrossRef]

45. Wenhua, L.; Hong, L.; Sao'an, C.; Jianqing, Z.; Chunan, C. Kinetics of photocatalytic degradation of aniline in water over TiO 2 supported on porous nickel. J. Photochem. Photobiol. A Chem. 2000, 131, 125-132. [CrossRef]

46. Hai, H.; Xiao, W.J.; Jian, Y.; Shi, J.W.; Chen, M.X.; Guan, W.F.S. Preparations of $\mathrm{TiO}_{2}$ film coated on foam nickel substrate by sol-gel processes and its photocatalytic activity for degradation of acetaldehyde. J. Environ. Sci. 2007, 19, 80-85.

47. Muktaridha, O.; Adlim, M.; Suhendrayatna, S.; Ismail, I. Progress of 3d metal-doped zinc oxide nanoparticles and the photocatalytic properties. Arab. J. Chem. 2021, 14, 103175. [CrossRef]

48. Fu, Y.S.; Li, J.; Li, J. Metal/semiconductor nanocomposites for photocatalysis: Fundamentals, structures, applications and properties. Nanomaterials 2019, 9, 359. [CrossRef]

49. Varnagiris, S.; Urbonavicius, M.; Sakalauskaite, S.; Demikyte, E.; Tuckute, S.; Lelis, M. Photocatalytic Inactivation of Salmonella typhimurium by Floating Carbon-Doped $\mathrm{TiO}_{2}$ Photocatalyst. Materials 2021, 14, 5681. [CrossRef]

50. Varnagiris, S.; Urbonavicius, M.; Sakalauskaite, S.; Daugelavicius, R.; Pranevicius, L.; Lelis, M.; Milcius, D. Floating TiO 2 photocatalyst for efficient inactivation of E. coli and decomposition of methylene blue solution. Sci. Total Environ. 2020, 720, 137600. [CrossRef]

51. Lelis, M.; Tuckute, S.; Varnagiris, S.; Urbonavicius, M.; Bockute, K.; Laukaitis, G. Synthesis and analysis of metallic Zn phase rich $\mathrm{ZnO}$ oxide films for the photocatalytic water treatment technologies. Mater. Today Proc. 2019, 33, 2484-2489. [CrossRef]

52. Sanders, E.R. Aseptic laboratory techniques: Plating methods. J. Vis. Exp. 2012, 1-18. [CrossRef] [PubMed]

53. Andersson, T.; Lood, R. Plaque Assay: A Method to Determine Viral Titer as Plaque Forming Units (PFU)। Protocol. JoVE Sci. Educ. Database 2020. Available online: https://www.jove.com/v/10514/plaque-assay-method-to-determine-viral-titer-asplaque-forming-units (accessed on 13 January 2022). 
54. Chankhanittha, T.; Komchoo, N.; Senasu, T.; Piriyanon, J.; Youngme, S.; Hemavibool, K.; Nanan, S. Silver decorated ZnO photocatalyst for effective removal of reactive red azo dye and ofloxacin antibiotic under solar light irradiation. Colloids Surfaces $A$ Physicochem. Eng. Asp. 2021, 626, 127034. [CrossRef]

55. Sarkar, C.; Basu, J.K.; Samanta, A.N. Synthesis of novel ZnO/Geopolymer nanocomposite photocatalyst for degradation of congo red dye under visible light. Environ. Nanotechnol. Monit. Manag. 2021, 16, 100521. [CrossRef]

56. Russo, M.; Iervolino, G.; Vaiano, V. W-Doped ZnO Photocatalyst for the Degradation of Glyphosate in Aqueous Solution. Catalysts 2021, 11, 234. [CrossRef]

57. Soudi, J.; Sandeep, K.M.; Sarojini, B.K.; Patil, P.S.; Maidur, S.R.; Balakrishna, K.M. Thermo-optic effects mediated self focusing mechanism and optical power limiting studies of $\mathrm{ZnO}$ thin films deposited on ITO coated PET substrates by RF magnetron sputtering under continuous wave laser regime. Optik 2021, 225, 165835. [CrossRef]

58. Kumar, V.; Singh, S.K.; Sharma, H.; Kumar, S.; Banerjee, M.K.; Vij, A. Investigation of structural and optical properties of ZnO thin films of different thickness grown by pulsed laser deposition method. Phys. B Condens. Matter 2019, 552, 221-226. [CrossRef]

59. Rashid, J.; Barakat, M.A.; Salah, N.; Habib, S.S. ZnO-nanoparticles thin films synthesized by RF sputtering for photocatalytic degradation of 2-chlorophenol in synthetic wastewater. J. Ind. Eng. Chem. 2015, 23, 134-139. [CrossRef]

60. Suwanboon, S.; Amornpitoksuk, P.; Sukolrat, A. Dependence of optical properties on doping metal, crystallite size and defect concentration of M-doped $\mathrm{ZnO}$ nanopowders ( $\mathrm{M}=\mathrm{Al}, \mathrm{Mg}$, Ti). Ceram. Int. 2011, 37, 1359-1365. [CrossRef]

61. Andolsi, Y.; Chaabouni, F. Optoelectronic properties of $\mathrm{Cr}$ doped $\mathrm{ZnO}$ thin films deposited by RF magnetron sputtering using a powder target. J. Alloys Compd. 2020, 818, 152739. [CrossRef]

62. Mangolini, F.; McClimon, J.B.; Rose, F.; Carpick, R.W. Accounting for nanometer-thick adventitious carbon contamination in X-ray absorption spectra of carbon-based materials. Anal. Chem. 2014, 86, 12258-12265. [CrossRef]

63. Le, T.K.; Nguyen, T.M.T.; Nguyen, H.T.P.; Nguyen, T.K.L.; Lund, T.; Nguyen, H.K.H.; Huynh, T.K.X. Enhanced photocatalytic activity of ZnO nanoparticles by surface modification with KF using thermal shock method. Arab. J. Chem. 2020, 13, 1032-1039. [CrossRef]

64. Pérez-González, M.; Tomás, S.A.; Santoyo-Salazar, J.; Morales-Luna, M. Enhanced photocatalytic activity of TiO $2-\mathrm{ZnO}$ thin films deposited by dc reactive magnetron sputtering. Ceram. Int. 2017, 43, 8831-8838. [CrossRef]

65. Yousef, A.; Barakat, N.A.M.; Amna, T.; Unnithan, A.R.; Al-Deyab, S.S.; Yong Kim, H. Influence of CdO-doping on the photoluminescence properties of $\mathrm{ZnO}$ nanofibers: Effective visible light photocatalyst for waste water treatment. J. Lumin. 2012, 132, 1668-1677. [CrossRef]

66. Alfaro Cruz, M.R.; Ceballos-Sanchez, O.; Luévano-Hipólito, E.; Torres-Martínez, L.M. ZnO thin films deposited by RF magnetron sputtering: Effects of the annealing and atmosphere conditions on the photocatalytic hydrogen production. Int. J. Hydrog. Energy 2018, 43, 10301-10310. [CrossRef]

67. Senthilraja, A.; Krishnakumar, B.; Subash, B.; Sobral, A.J.F.N.; Swaminathan, M.; Shanthi, M. Sn loaded Au-ZnO photocatalyst for the degradation of AR 18 dye under UV-A light. J. Ind. Eng. Chem. 2016, 33, 51-58. [CrossRef]

68. Khudhair, E.M.; Ammar, S.H.; Khadim, H.J. Phosphotungstic acid immobilized onto ZnO coated zerovalent iron (Fe@ZnO/PW) core/shell magnetic nanocomposite for enhanced photocatalytic bacterial inactivation under visible light. J. Photochem. Photobiol. A Chem. 2021, 404, 112907. [CrossRef]

69. Singh, P.; Kumar, R.; Singh, R.K. Progress on Transition Metal-Doped ZnO Nanoparticles and Its Application. Ind. Eng. Chem. Res. 2019, 58, 17130-17163. [CrossRef]

70. Gnanamozhi, P.; Renganathan, V.; Chen, S.-M.; Pandiyan, V.; Antony Arockiaraj, M.; Alharbi, N.S.; Kadaikunnan, S.; Khaled, J.M.; Alanzi, K.F. Influence of Nickel concentration on the photocatalytic dye degradation (methylene blue and reactive red 120) and antibacterial activity of $\mathrm{ZnO}$ nanoparticles. Ceram. Int. 2020, 46, 18322-18330. [CrossRef]

71. Macomber, L.; Hausinger, R.P. Mechanisms of nickel toxicity in microorganisms. Metallomics 2011, 3, 1153. [CrossRef]

72. Giaouris, E.; Heir, E.; Desvaux, M.; Hébraud, M.; Møretrø, T.; Langsrud, S.; Doulgeraki, A.; Nychas, G.-J.; Kačániová, M.; Czaczyk, K.; et al. Intra- and inter-species interactions within biofilms of important foodborne bacterial pathogens. Front. Microbiol. 2015, 6, 841. [CrossRef]

73. Jebri, S.; Rahmani, F.; Hmaied, F. Bacteriophages as antibiotic resistance genes carriers in agro-food systems. J. Appl. Microbiol. 2021, 130, 688-698. [CrossRef] 